IZA DP No. 7695

Determinants of Financial Rewards from Industry-University Collaboration in South Korea

Junghee Han

Almas Heshmati

October 2013 


\title{
Determinants of Financial Rewards from Industry-University Collaboration in South Korea
}

\author{
Junghee Han \\ Chonnam National University
}

Almas Heshmati

Sogang University

and IZA

\section{Discussion Paper No. 7695 \\ October 2013}

\author{
IZA \\ P.O. Box 7240 \\ 53072 Bonn \\ Germany \\ Phone: +49-228-3894-0 \\ Fax: +49-228-3894-180 \\ E-mail: iza@iza.org
}

Any opinions expressed here are those of the author(s) and not those of IZA. Research published in this series may include views on policy, but the institute itself takes no institutional policy positions. The IZA research network is committed to the IZA Guiding Principles of Research Integrity.

The Institute for the Study of Labor (IZA) in Bonn is a local and virtual international research center and a place of communication between science, politics and business. IZA is an independent nonprofit organization supported by Deutsche Post Foundation. The center is associated with the University of Bonn and offers a stimulating research environment through its international network, workshops and conferences, data service, project support, research visits and doctoral program. IZA engages in (i) original and internationally competitive research in all fields of labor economics, (ii) development of policy concepts, and (iii) dissemination of research results and concepts to the interested public.

IZA Discussion Papers often represent preliminary work and are circulated to encourage discussion. Citation of such a paper should account for its provisional character. A revised version may be available directly from the author. 


\section{ABSTRACT \\ Determinants of Financial Rewards from Industry-University Collaboration in South Korea}

The external circumstances for universities have been changing rapidly. In order to be competitive, survive, and flourish, universities have shown a growing enthusiasm to generate financial revenues externally. The literature refers to this phenomenon as academic capitalism, defined as the involvement of colleges and faculties in market-like behaviors, which has become a key feature of higher education finances in most countries. As a result, technology transfer, technology commercialization, and patents awarded via industryuniversity collaboration represent a source of financial rewards. This paper explores the determinants of financial rewards of universities sources from industry-university collaboration in South Korea. We find that among the determinants of financial performances, technology transfer per employee working at technology licensing offices, participation of engineering faculty, patent approvals, the volume of research funds, the number of employees, and firms in incubators within universities turn out to be significant contributors to externally sourced university revenues. Technology commercialization using technology transfer and incentive rules for developers are not statistically significant. In the light of these findings, it appears that an industry-university cooperation foundation program is likely to play a strong role in private university finances in Korea.

JEL Classification: A20, D45, I22, L24, P12

Keywords: industry-university collaboration, entrepreneurial university, university revenues, South Korea

Corresponding author:

Almas Heshmati

Department of Economics

Sogang University

Room K526

35 Baekbeom-Ro (Sinsu-Dong \#1), Mapo-Gu

Seoul 121-742

Korea

E-mail: heshmati@sogang.ac.kr 


\section{Introduction}

Promoting the industry-university collaboration is a major policy priority in Korea. The motive behind such policy initiative is to make the nation's system of innovation as well as the financial reward condition for the universities more dynamic. Though industry-university collaboration has various facets, the financial rewards are crucial considering the entrepreneurial university is pursuing profitability by using product of knowledge, technology innovation, and collaboration with industry (Slaughter and Leslie, 1997; Slaughter and Rhoades, 2004; Rhoades and Slaughter, 2004; Clarks, 1998; Washburn, 2005; Geiger, 2004; Geiger and Creso, 2005; and Hayrinen-Alestalo and Peltola, 2006; Naido, 2005).

When it comes to the university's role, it is primarily teaching and conducting basic research that dominate and are given the highest priority, but currently university entrepreneurship (Clark, 1998; Sporn, 2001; Etzkowitz et al., 2000; Etzkowitz, 2004; Bercowitz and Feldman 2006; Wong, 2007; Rothaermal, Agung and Jiang, 2007) is also increasingly the focus of attention. Not surprisingly, university actions such as technology transfer and commercialization have been much studied in recent years, because those are the mechanism for earning financial rewards as well as economic growth in the US education system (Vallas and Kleinman, 2008; Wayne, 2010).

Most universities in Korea have Industry-University Cooperation Foundation (hereafter IUCF) since the Industry-University Collaboration law of 2003 (hereafter IUC law) was introduced by the Korean government in 2003. Subsequently, promoting industry-university collaboration (hereafter IUC) activities has become a major public policy in Korea as demonstrated by a series of legislative actions, such as the 2008 revised IUC law which permits universities to establish a holding company.

The IUC law dramatically changed the incentive system for universities. Prior to the setup of IUCF, Korean universities were not only inactive in pursuing their own revenues but also did not have the status of legal persons who are in charge of it and therefore could not claim direct incomes. Thus, Korean universities have been able to generate financial revenues via IUC activities under IUC law. IUC law in Korea is similar to the Bayh-Dole Act in the United States.

This paper explores the determinants of financial reward of Korean universities through IUC activities including university features and external conditions. Unlike previous literature regarding performance mainly induced by IUC activities, the reason we use many variables including university features and external conditions is that IUC activities take place with a variety of aspects.

Pressured from the rapidly changing external circumstances, universities have shown a growing enthusiasm to generate financial revenues externally in order to survive. Thus, this paper focuses on commercial output factors contributing to the creation of income of universities in Korea. In order to achieve the aims, in the empirical part of this research, data containing the performance of 139 universities during 2008-2010 in Korea are utilized. Few previous studies have dealt with financial revenues obtained via industry-university collaboration, while numerous papers have dealt with performance of IUC activities such as the number of technology transfer, patents, and start-ups. In this respect, it is meaningful to find determinants about the university behaviors which are aimed to acquire financial revenue.

This paper is structured as follows. Section 2 presents review of literature on university revenue generated from external collaborative activities in general and in Korea in particular. Section 3 describes the data set used in the empirical part of this 
study. Section 4 introduces the model used and explains the regression results from determinants of university revenues. In the final section, the results are summarized and a conclusion and discussion of the role of the university is provided.

\section{Literature Review and Research Hypothesis}

The university's role by tradition is primarily teaching and research, which are given the highest priority. However, increased competition and limited financial resources have led to the development of university entrepreneurship. This issue is discussed in Slaughter and Leslies (1997) and Slaughter and Rhoades (2004). A number of other studies also discuss university entrepreneurship (Clark, 1998; Sporn, 2001; Etzkowitz et al., 2000; Etzkowitz, 2004; Bercowitz and Feldman 2006; Wong, 2007; Rothaermal, Agung and Jiang, 2007). Slaughter and Rhoades (2004) contend that securing external finances is critical for university survival in order to respond to the new economic and changed environment. Appendix A presents research conducted to investigate the effects of factors and policy instruments such as subsidies, research policy, intellectual property, and industry-university collaboration.

When it comes to entrepreneurial universities, American universities have been involved in entrepreneurship dating back to the Bayh-Dole Act of 1980, which allowed the ownership of patents generated by use of Federal Research Funds (Rothaermal, Agung and Jiang, 2007). The goal of the Bayh-Dole Act was to facilitate the commercialization of university technology (Kenney and Patton, 2009; Shane, 2004). According to the findings from Taylor et al. (2011), entrepreneurship has been robust and prevalent in the Bayh-Dole era. Clearly, the Federal government expects universities to pursue more collaborative research with industry and conduct more commercialization than ever before. The development can be considered government wishes to foster various activities of university-industry collaboration. The objective is that universities can directly earn revenues using their own resources, such as patents, technology licensing, and facilities as well as research and development collaborations.

Etzkowitz (2003) stated that in order to be an entrepreneur a university has to have a considerable degree of independence from the state and industry, but also a high degree of interaction with institutions' various spheres. University research groups, socalled academic research and start-ups, have a common focus on rewards of recognition and finance (Etzkowitz, 2003). Licensing, joint ventures, marketing, and sales of products provide ways of and encourage disseminating knowledge to regions above and beyond the traditional means of academic dissemination. Slaughter and Rhoades (2004) emphasize that public colleges and universities faced with a major loss in state support are seeking to sell a wide range of products coming from university resources commercially as a basic source of income.

The most galvanizing event affecting industry-university collaboration, for instance, was the technology transfer of the Bayh-Dole Act of 1980. The Bayh-Dole Act dramatically changed the incentive system for universities (Clayton-Mathews, 2001). After that, universities became interested in commercialization using internal resources. Managerially, important performance factors of IUC activities include personal evaluation institutions and reward systems (Siegel et al, 2003a and 2003b). Joshua and Patricia (2005) showed that there is a positive relationship between performance and age of Technology Transfer Organization (TTO) and between performance and the number of distinguished engineering faculty members, respectively. 
Universities seek research funds, star faculty members, top quality student and outcomes, at least among institutions competing to advance their reputations for excellence. Thus, while a university may hate characterizing itself as being part of a market or in competition just as for-profit firms, the reality is that the environment has become increasingly competitive and market-like (Zemsky et al., 1997). A comprehensive review of the previous research regarding performance of industryuniversity collaboration is summarized in Appendix B.

Kwon and Han (2009) conducted research in regard to performance from IUC activities in Korea. They suggested 7 hypotheses linked with performance of universities including (1) the age of the university; (2) the institutional ownership differences of the university; (3) scales of the university; (4) location of the university; (5) specialties such as the research-driven university; (6) amount of research funds; (7) the number of institutions offering research funds. All of these hypotheses had a positive effect on performances. Hypothesis and were verified by using regression and a survey of 169 universities in Korea.

According to the findings, Kwon and Han (2009) showed that public universities have made more revenues through the number of technology transfers and the amount of technology licensing fees than those of private universities. Also in this article, it is shown that other factors such as the age of universities, size of universities (e.g. number of departments or faculties), and location of university are not related statistically to performances of IUC activities. In terms of research funding, funds coming from industry have positive effects on performances while public funds do not affect their performance.

Power (2003) showed that the volume of research fund including both public and private has positive correlation for patent products in United States. However, it is not related to revenue through the licensing. Also, Power (2003) showed that the more distinguished faculty members a university has, the more patents licensing will it generate.

According to the white paper released (KRF, 2012), the number of technology licensing offices (TLOs) increased rapidly over time (see Kim, 2005). There are numerous empirical studies regarding performance of IUC activities such as technology transfer, patents, and spin-offs while there are few studies on determinants of revenue from IUC activities in Korea as well as other countries. Considering IUC activities with a variety of aspects and from reviewing previous literature, this study sets up 3 hypotheses outlined below. Appendix Figure 1 shows the research model.

Hypothesis 1: University features are related with revenues generated via industryuniversity collaboration.

H1a: School entity is related with revenues generated via industry-university collaboration.

H1b: School scale (number of faculty members, students, graduate students, staffs, departments) is related with revenues.

H1c: School location is related with revenues generated via industry-university collaboration.

H1d: School characteristics (uniqueness, specialty, number of natural and engineering faculty members, and number of distinguished scholars) are related with revenues generated via industry-university collaboration. 
Kim and Lee (2007) analyze the relationships between performance of IUC activities and university competency factors such as research competency and managerial competency through multivariate regression analysis exploring other research questions. According to the findings, research competency such as the number of SCIE papers and patent registrations were significant, but managerial competency such as the scale of technology transfer organization and the number of specialists was not statistically significant. Kim and Lee's findings showed the different results from Kwon and Han's (2009) findings regarding research competency variables such as the number of SCIE papers. Comparing the findings from two studies, by Kim and Lee (2007) and Kwon and Han (2009), the number of SCIE papers is a significant predictor in the former but not in the latter.

Regarding the operation of universities, Byun (2004) showed that research-driven universities created more results than those of educationally-driven universities in terms of the number of papers, technology transfers, and income from technology licensing offices. Audretsch (2007) indicates a highly educated workforce that is capable of creating and moving innovative technologies into the marketplace is a critical component of the current entrepreneurial university.

When looking at the current categories and forms of IUC activities in Korea, there have been many activities including mobility of workforce such as internships, graduate placements, and temporary exchange of personnel. Other key activities include; 1) publications such as co-authorship; 2) cooperation in R\&D activities such as establishment of research divisions, joint $R \& D$ projects, supervision of a trainee or Ph.D. students, sponsoring of research; and participation in conference and networks; 3) sharing of facilities such as shared laboratories, joint use of machines, public location of buildings, and purchasing of prototypes; 4) cooperation in education, such as contract education or training, working students, influencing curricula of university programs, providing scholarships, and sponsoring of education; 5) formal contract research and advising, such as contract-based research and contract-based consultancy; 6) intellectual property rights, such as patents, co-patenting, licensing of university-held patents, copyright and other forms of intellectual property; 7) spin-offs and entrepreneurship, start-ups, incubators at universities, and stimulating entrepreneurship.

According to a white paper containing IUC activities released in 2012, the number of staff members in industry-university cooperation foundations is likely to increase more than that of university staff members. These meaningful changes show the evidence that the authority of universities is more interested in fostering the industryuniversity cooperation foundation than it has been in the past. Looking at the revenue structure for 139 universities, there were a number of income items, which are critical for evaluation and performance of IUCF.

The second set of hypotheses is related to revenues from IUCF performance, rules, and workforce. The research capacity is outlined as follows.

Hypothesis 2: IUCF function is related with revenues generated via industry-university collaboration.

H2a: IUCF performances (volume of profit of technology transfer, technology commercialization, number of published papers, patent approvals and SCI papers) are related with revenues via industry-university collaboration.

H2b: Rules in IUCF (incentive system for right of ownership, reward for inventor) are 
related with revenue from industry-university collaboration.

H2c: Research capacity (number of technology transfers, research funds from industry, number of firms at technology incubators, firms governed by universities) is related with revenues from industry-university collaboration.

H2d: Workforce in IUCF (number of staff TTO members, distinguished faculty members, and faculty members with firm experience) is related with revenues from industry-university collaboration.

When large a number of firms are located near the university, collaboration between university and enterprises more easily takes place (Han, 2006). The purpose of clustering policies being operated since the 1990s in Korea is to enhance industryuniversity collaboration. The agglomeration has a positive relationship between universities and industries. Friedman and Silberman (2003) showed that the degree of proximity of high-tech firms near schools has a positive effect on technology transfer. Geographical location of university also has a positive relation with knowledge spillover (Jaffe et al., 1993). Audretsch and Feldman (1996) asserted that research productivity is inclined to increase in more agglomerated regions. According to Agrawal (2000), the distance from MIT has propensity towards successful technology transfer and technology commercialization. Kwon and Han (2009) showed that universities located in rural areas in Korea have higher performance than universities located in urban areas in terms of technology transfer. Thursby and Thursby (2002) showed that relationship with external firms is affected by their performance.

The third set of hypotheses on the relationship between external conditions and university revenues is formulated as follows.

Hypothesis 3: External condition is related with revenues generated from industryuniversity collaboration.

H3a: The number of venture firms located near universities is related with revenues from industry-university collaboration.

H3b: The number of enterprises located near universities is related with revenues from industry-university collaboration.

H3c: The total product volume of firms is related with revenues from industryuniversity collaboration.

H3d: The amount of public research funds received is related with revenues from industry-university collaboration.

\section{Descriptions of Data and Estimation Procedures}

In this study, different datasets collected from 2008-2010 by the Ministry of Education, Science and Technology, Korea Education Development Institute, Korea Foundation for the Promotion of Private Schools, and National Research Foundation of Korea were used for econometric analysis. Data were selected from 139 of 148 universities that have been running the IUCF. The assembled dataset was composed of 38 variables which could be related to university revenues.

For a matter of sensitivity analysis of the results, both full and reduced model specifications are used and tested to specify a suitable model to determine university revenues. Multivariate regression analysis was used for estimation using the OLS method with robust standard errors. 
As of 2010, the total university revenue from the results of activities of IUCFs was 1 trillion won. Considering average revenue, each IUCF received 22.8 billion won, of which IUCF's revenue is 6.8 billion won. When looking over the structure of revenues, we note that revenue obtained through co-research is 851.4 billion won, while revenue sourced from original educational operations is 52.4 billion won. Other revenue source such as other informal contacts is estimated to reach 48.4 billion won. Revenue obtained through intellectual property rights and technology licensing is 30.9 billion won, and revenue obtained through using facilities such as sharing laboratories is 19.7 billion won. These make up the first through fifth highest levels, respectively. As collaborative relations between universities and industries deepen, we can find that financial rewards obtained via IUC activities increase. Appendix C presents all the variables used in our econometric model.

In spite of the short history related to external financial activities, 139 universities have facilitated IUC activities eagerly. Regarding the ownership of universities, 28 (20.0\%) of 139 universities are national or regional universities. More than 79 universities are private universities. In Korea, age of universities, number of graduate students and distinguished scholars are important factors determining the flow of external revenues for research-driven universities. When it comes to location of universities, 50 (36.0\%) universities are located in Seoul or the Kyunggi region. In fact, location of university has been considered a critical factor for development of universities in Korea.

Seventy-nine universities (57.0\%) have less than 5 technology commercialization through technology transfer. The data summary showed that more than half of universities 54 (38.8\%) have had no successful commercialization in the previous 3 years. When looking over the number of technology transfers per staff members working at TLO, 60 (43.2\%) universities have no results per staff member. The number of universities with a technology transfer division is 107 (77\%). From the data, it is evident that more than $77 \%$ of universities have been conducting technology transfer. Distinguished scholar is defined as those who are enrolled at Marquis Who's Who are used. As human resources, the number of faculty members, the number of undergraduate and graduate students, staff members, and internship students are used. The dispersion is very wide. Total research fund, and subsidy volume are wide. The number of faculty members belonging to natural and engineering department, undergraduate students, graduate students, and distinguished scholars differs also depending on school age.

In regards to the number of faculty members we notice a large gap (from 24 to 2,025). The number of domestic patents ranges from 55 to 743 while the number of patents registered at foreign countries ranges from 1.27 to 51.7. Considering these statistics, patent activities are produced domestically rather than those produced in foreign countries. There are big differences regarding research funding, which may lead to the research activities gap that is widening among universities.

The total space size of laboratories is also interesting to this study. The reason this variable is considered is that the total size of laboratories stands for capacity and competency regarding $\mathrm{R} \& \mathrm{D}$ activities and their outcomes.

Considering geographical environment of IUC activities, the total sale and total product of regional firms are used. With regard to the IUC activity capabilities, the number of venture firms, technology incubators, technology transfer divisions, and the total size of laboratories are used. With regard to university policy capability, school 
rule for ownership rights for inventors, and reward incentives, rules are used. The Korean government also strongly facilitates rules in order to boost the invention of new technologies. As performance of industry-university cooperation capabilities, total sale of a university's firms, the number of technology commercialization, the number of technology transfers, the number of domestic and foreign patent approvals, and publications are used. As a dependent variable, revenue, (defined as total income from all kinds of IUC activities over 3 years) is used.

The original 44 variables are reduced to 21 variables in order to estimate and analyze the data effectively. For instance, to define the variable patents, the number of applications and approvals are merged into one. Some of these variables are university specific such as human resources, facilities, research funds, and rules, while others are location specific such as regional firms. Numerous combinations of variables are used in order to obtain the best set of variables that explains variations in the dependent variable regarding financing results, as well as accounts for the heterogeneity of the universities in our model specification.

The correlation matrix of dependent and independent variables (not reported here) showed that with the exception of some variables, the correlation between the independent variables is not so high, suggesting that multicollinearity is not a serious problem. The high correlation between revenue and the number of patent applications including those registered at foreign countries, the amount of total research funds, which represent the size of universities indicates that larger universities have a larger number of faculty members and experts. Given the high correlation between these two variables, one of them could be deleted; however, the number of workforces determines the size of a university. As the amount of total research funds could be determined by the number of faculty members and experts, the size of university or age of university are highly and strongly related to revenue than others factors.

Summary statistics of the data are reported in Table 1 . There is evidence of a large dispersion in revenues and its explanatory variables among the universities. The large dispersion and the significant t-values are in support of large heterogeneity among the universities.

Table 1: Summary statistics of the data, period 2010-2011, N=139 universities.

\begin{tabular}{|c|c|c|c|c|}
\hline Variable & Definition of variables & Mean & Std Dev & t-value \\
\hline Revenue & $\begin{array}{l}\text { Amount of revenue through university-industry } \\
\text { collaboration }\end{array}$ & 7271498.000 & 23349053.000 & 3.67 \\
\hline Specialty & $\begin{array}{l}\text { If the number of graduate students is more than } 10 \% \text { of } \\
\text { total enrollment numbers at school } 1\end{array}$ & 0.439 & 0.498 & 10.39 \\
\hline facueng & Number of faculty members in engineering departments & 156.820. & 139.900 & 13.22 \\
\hline undstud & Number of undergraduate students & 9894.907 & 6362.971 & 18.33 \\
\hline Distisch & $\begin{array}{l}\text { Number of distinguished scholars enrolled in Marquis } \\
\text { Who's Who }\end{array}$ & 18.568 & 26.624 & 8.22 \\
\hline Pappubl & $\begin{array}{l}\text { Number of published papers including those published in } \\
\text { foreign journals }\end{array}$ & 113.995 & 148.510 & 9.05 \\
\hline Patappl & $\begin{array}{l}\text { Number of patent applications including those registered } \\
\text { in foreign countries }\end{array}$ & 63.199 & 129.214 & 5.77 \\
\hline Resfund & Amount of total research funds & 22708011.000 & 45361537.000 & 5.90 \\
\hline Placres & Total space volume for research activities (facilities) & 86012.570 & 72720.040 & 13.94 \\
\hline Stafuni & Number of staffs at school & 214.014 & 176.157 & 14.32 \\
\hline Uninfun & $\begin{array}{l}\text { Amount of industry-university cooperation fund received } \\
\text { by university and industry }\end{array}$ & 3017228.000 & 6781986.000 & 5.25 \\
\hline
\end{tabular}




\begin{tabular}{|l|l|r|r|r|}
\hline Volsubs & Amount of total public funds received by government & 41634145.000 & 73566382.000 & 6.67 \\
\hline Totsalr & Total sales of the firms owned by school & 103091.200 & 85181.360 & 14.27 \\
\hline nstafuid & $\begin{array}{l}\text { Number of staffs in industry-university cooperation } \\
\text { foundation (IUCF) }\end{array}$ & 17.7623 & 16.532 & 12.67 \\
\hline agetectr & $\begin{array}{l}\text { Number of commercialization through technology } \\
\text { transfer }\end{array}$ & 3.633 & 3.264 & 13.12 \\
\hline nstafttd & $\begin{array}{l}\text { Number of technology transfers per staff who are working } \\
\text { at technology transfer division }\end{array}$ & 1.358 & 1.818 & 8.81 \\
\hline techtdiv & Technology transfer division & 0.338 & 0.475 & 8.40 \\
\hline Studint & Number of student participating in internships & 813.374 & 626.757 & 4.01 \\
\hline Techtra & Number of technology transfer & 167 & 12.725 & 7.59 \\
\hline Profttr & Amount of profits through technology transfer & 17.187 & 13.775 & 14.71 \\
\hline Ntecincb & Number of firms within technology incubator at school & & 412185.900 & 4.69 \\
\hline \hline
\end{tabular}

\section{Results and Implications}

This part explores the determinants of university revenue based on analysis of entrepreneurial university data. It should be noted that the dependent variables, revenue in regression analysis here, is taken from the National Research Foundation of Korea from 2008 to 2010, while independent variables are obtained from the Ministry of Education and Technology and Korea Foundation for Promotion of Private School from 2008 to 2010. Both sets are the most recent available data. Thus we can interpret the results as a relationship with 3-year lags. The regression results for different model specifications are reported in Table 2.

Table 2: OLS results of the general and reduced models, $n=139$ observations.

\begin{tabular}{|c|c|c|c|c|c|c|c|c|}
\hline \multirow[t]{2}{*}{ Variables } & \multicolumn{4}{|c|}{ General Model } & \multicolumn{4}{|c|}{ Reduced Model } \\
\hline & $\begin{array}{l}\text { Parameter } \\
\text { Estimate }\end{array}$ & $\begin{array}{c}\text { Robust Std } \\
\text { Error }\end{array}$ & t-value & $\operatorname{Pr}>\mid t$ & $\begin{array}{l}\text { Parameter } \\
\text { Estimate }\end{array}$ & $\begin{array}{l}\text { Robust } \\
\text { Std Error }\end{array}$ & t-value & $\operatorname{Pr}>\mid t$ \\
\hline Intercept & 7.6291 & 5.8310 & 1.31 & 0.1937 & 4.9432 & 1.8042 & 2.74 & 0.0071 \\
\hline ownship & 0.2201 & 0.6545 & 0.34 & 0.7373 & - & - & - & - \\
\hline locaton & -0.2917 & 0.3556 & -0.82 & 0.4141 & - & - & - & - \\
\hline special & 0.3904 & 0.2630 & 1.48 & 0.1409 & 0.3918 & 0.2237 & 1.75 & 0.0824 \\
\hline unique & -0.1800 & 0.2704 & -0.67 & 0.5072 & - & - & - & - \\
\hline schoage & -0.0940 & 0.1563 & -0.60 & 0.5488 & - & - & - & - \\
\hline lfaculty & -0.1283 & 0.3993 & -0.32 & 0.7486 & - & - & - & - \\
\hline lfacueng & 0.3694 & 0.1749 & 2.11 & 0.0371 & 0.3012 & 0.1513 & 1.99 & 0.0489 \\
\hline lgrastud & 0.0114 & 0.0506 & 0.23 & 0.8217 & - & - & - & - \\
\hline lundstud & -0.5655 & 0.2895 & -1.95 & 0.0536 & -0.6351 & 0.2424 & -2.62 & 0.0099 \\
\hline ldistsch & -0.3203 & 0.1548 & -2.07 & 0.0411 & -0.3023 & 0.1404 & -2.15 & 0.0333 \\
\hline lpappubl & -0.2047 & 0.1823 & -1.12 & 0.2642 & -0.2881 & 0.1411 & -2.04 & 0.0434 \\
\hline lpatappl & 0.3824 & 0.1753 & 2.18 & 0.0315 & 0.4111 & 0.1386 & 2.97 & 0.0036 \\
\hline lpatappr & 0.0750 & 0.1129 & 0.66 & 0.5081 & - & - & - & - \\
\hline lunibudg & -0.1142 & 0.4604 & -0.25 & 0.8046 & - & - & - & - \\
\hline lresfund & 0.3780 & 0.0756 & 5.00 & 0.0001 & 0.3874 & 0.0697 & 5.55 & 0.0001 \\
\hline lpriinst & -0.0005 & 0.0363 & -0.01 & 0.9898 & - & - & - & - \\
\hline lplacres & 0.4392 & 0.3035 & 1.45 & 0.1510 & 0.4094 & 0.2290 & 1.79 & 0.0765 \\
\hline lstafuni & 0.4276 & 0.3211 & 1.33 & 0.1861 & 0.4185 & 0.2475 & 1.69 & 0.0935 \\
\hline lfexpfac & 0.0024 & 0.0639 & 0.04 & 0.9701 & - & - & - & - \\
\hline luninfun & 0.0382 & 0.0303 & 1.26 & 0.2103 & 0.0468 & 0.0273 & 1.71 & 0.0898 \\
\hline lvolsubs & -0.1563 & 0.0441 & -3.54 & 0.0006 & -0.1585 & 0.0380 & -4.17 & 0.0001 \\
\hline lfirmreg & -0.0547 & 0.0881 & -0.62 & 0.5357 & - & - & - & - \\
\hline ltotsalr & 0.0048 & 0.0520 & 0.09 & 0.9261 & - & - & - & - \\
\hline ltotprod & 0.2278 & 0.1621 & 1.41 & 0.1629 & 0.2837 & 0.0820 & 3.46 & 0.0008 \\
\hline nstafuid & 0.0093 & 0.0062 & 1.50 & 0.1379 & 0.0084 & 0.0064 & 1.32 & 0.1883 \\
\hline agetectr & 0.0416 & 0.0312 & 1.33 & 0.1859 & 0.0301 & 0.0319 & 0.94 & 0.3472 \\
\hline
\end{tabular}




\begin{tabular}{|l|r|r|r|r|r|r|r|r|}
\hline \hline nstafttd & 0.1133 & 0.0541 & 2.10 & 0.0385 & 0.1340 & 0.0525 & 2.55 & 0.0120 \\
\hline rulerown & 0.2211 & 0.3297 & 0.67 & 0.5040 & - & - & - & - \\
\hline rulerinv & -0.0124 & 0.2705 & -0.05 & 0.9636 & - & - & - & - \\
\hline rulerett & -0.2117 & 0.1908 & -1.11 & 0.2698 & - & - & - & - \\
\hline techtdiv & -0.2056 & 0.2045 & -1.00 & 0.3173 & -0.2515 & 0.1880 & -1.34 & 0.1836 \\
\hline lstudint & 0.0581 & 0.0378 & 1.54 & 0.1277 & 0.0501 & 0.0360 & 1.39 & 0.1674 \\
\hline ltechtra & -0.1396 & 0.1103 & -1.27 & 0.2086 & -0.1608 & 0.1062 & -1.51 & 0.1327 \\
\hline lprofttr & -0.0381 & 0.0250 & -1.52 & 0.1312 & -0.0357 & 0.0229 & -1.56 & 0.1215 \\
\hline lvenfirm & 0.0134 & 0.1038 & 0.13 & 0.8974 & - & - & - & - \\
\hline ltotsals & -0.0099 & 0.0146 & -0.68 & 0.4967 & - & - & - & - \\
\hline nschfirm & -0.0483 & 0.0756 & -0.64 & 0.5243 & - & - & - & - \\
\hline ntecincb & 0.0176 & 0.0063 & 2.80 & 0.0061 & 0.0172 & 0.0061 & 2.83 & 0.0054 \\
\hline & & & & & & & & \\
\hline RMSE & 0.9873 & & & & & & & \\
\hline R2 adjusted & 0.6860 & & & & & & \\
\hline \hline
\end{tabular}

Two models are estimated: a general model and a reduced counterpart. The reduced model differs from the general by most insignificant variables being restricted to have zero effects. Thus, the full set of variables, 38 in number previously presented, are also utilized for analysis in the general model specification. Table 5 presents the estimation results from the two nested models examining the determinants of university revenues by utilizing IUCF. It is a fact that only 10 variables are statistically significant among 38 variables at the $5 \%$ level of significance and another 4 at the $10 \%$ level in the restricted model. The main findings are described as follows.

The university features must first be considered. According to Table 2, the number of faculty members with specialty in engineering departments is related to the determinant of revenue as several previous studies forecasted (Kwon and Han, 2009). In fact, faculty members at engineering departments have mainly participated in IUC activities rather than other departments.

Interestingly, hypothesis 1a is rejected statistically. This result is quite a difference from findings (Kwon and Han, 2009) which suggested that public universities have higher performances than those of private universities. This result informs that performances do not affect revenues statistically let alone university entities.

School scale (H1b) classified by the number of total faculty members, undergraduate students, graduate students, staffs, and departments is not statistically significant. This result differs from previous findings (O’Shea et al., 2005; Byun, 2004). These results mean that universities in Korea, regardless of scale and entity, have yet to be entrepreneurial universities.

School location (H1c) has no statistically significant relationship with revenue. This result differs from findings (Kwon and Han, 2009) that universities located in rural regions have higher performance than universities in urban areas.

From the results regarding school characteristics (H1d), we find that the number of distinguished scholars is negatively affecting financial results. This finding differs from previous results (Power, 2003; Power and McDougall, 2005; Joshua \& Patricia, 2003); Jensen and Thursby, 2003. In this paper, the number of distinguished scholars is defined as faculty members who have been enrolled in Marquis Who's Who. They are faculty members who might be eager to research at high quality level academically rather empirically. Of course, they could be contributed to develop for academia, the so-called ivory tower, but this is another story regarding generating revenue. It can be assumed that their research activities are negatively affecting financial results.

When examining the analysis of IUCF performance, we find that patent approval (H2a) is statistically related to revenue as we had expected (Thursby and Thursby, 2002; 
Kwon and Han, 2009; Kim and Lee, 2007; Sapsalis et al., 2006). Unlike what we expected, published papers are negatively significant. It can be assumed that Korean universities tend to do research focusing on academics rather than applied research intended to make revenue. Because in order to achieve academic research outputs, much research funding is needed.

Somewhat surprisingly, the rule for intellectual property rights rewards (H2b) from invention is shown to be statistically obscure. This result shows opposite findings compared with those of Byun (2004). Byun (2004) carried out research regarding incentive systems using survey methodology. What the opposite finding differs from Byun's research might be originated from methodology. Comparing with the history of entrepreneurial universities in United States, Korean universities have a relatively short experience. Korean universities have changed fast in the direction of entrepreneurial universities using IUCF.

When examining results of research capacity (H2c), we find that the number of technology transfers, research funds, and the number of firms at technology incubators are each statistically related to revenue. Recently, Korean universities have been trying to improve the IUC activities; for example, buildings designated as a center of IUCF, establishing technology incubator, or start-ups.

Hypothesis $2 \mathrm{~d}$ is statistically insignificant except for the number of staffs at TTO (Thursby and Thursby, 2002). Productivity brought by workforces is very important for revenue.

From the raw data, in 2010, the number of patent applications, the number of staffs dealing with technology transfer increased more conspicuously than in previous years. Results have given interesting findings. Currently, most universities have been hiring faculty members who have work experience at enterprises as experts. The number of firms in technology incubators indicating firms pursuing their own profits which belong to universities is shown to be positive and statistically significant, which underscores the importance of the firm's activities to make money.

According to previous studies, the relation between universities and external conditions had a positive effect on performance (Jaffe et al., 1993; Joshua and Patricia, 2002; Thursby and Thursby, 2002; Friedman and Silberman, 2003). However, the hypotheses group 3, which are on the relation between university and firms located near schools, are statistically insignificant except for the total product volume of firms existing near the university (H3c).

Generally, universities may play an educational role as well as promote innovation activities at firms in the region. So, when a university is located in proximity to firms, collaboration activities such as knowledge spillover and technology transfer take place more easily. Moreover, if firm size and firm characteristics are appropriate to interaction, universities' contribution through IUC activities will be more fruitful. From these results, we can interpret that regional economic volumes created by firms can affect university revenue.

Another conspicuous finding is research funds received by the government. Public subsidies are found to have a statistically negative effect on revenue unlike several previous research findings (Foltz et al., 2000; Power, 2003; Power and McDougall, 2005; Kwon and Han, 2009). Kwon and Han (2009) found that the volume of research funds including central government subsidies is positively affecting the performance. Of course, this paper shows that the total volume of research funds received by industry and university itself is positively affecting financial results. From the above results, we 
can conclude that even though government subsidies have an important role to increase research performance, they have not been related to revenue generation. On the flip side, it can be assumed that faculty members who have implemented research by using public subsidies cannot get directly involved in the research related to revenue generation because public subsidies have a clear goal such as development of future rudimentary technology.

\section{Summary and Conclusion}

Originally, universities pursued education, academic research or a combination of the two. IUCFs have been established since the enactment of the IUC law of 2003. In particular, universities have tried more intensively to pursue financial reward in earnest after the revised IUC law of 2008.

This study has utilized the National Research Foundation of Korea data and Ministry of Education and Technology and Korea Foundation for Promotion of Private School from 2008-2010 in analysis of financial rewards from university-industry research cooperation. In spite of the short period of IUCF, Korean universities have pursued entrepreneurial activities in a competitive educational market.

Synthesizing the findings, the establishment of industry-university cooperation foundation (IUCF) seems to be on the right track. However, it is bound to take a long time to adjust to the entrepreneurial university. The main findings are as follows.

Firstly, the number of technology transfers, the total research funds, and the number of faculty members in natural science and engineering are important determinants of revenue. This finding is the same as those advanced universities in United States. Typically, IUC activities have mainly occurred in engineering departments. However, regarding the determinant of the number of outstanding engineering faculty members, it is in contrast to the results from the United States, and reflects the latecomer entrepreneurial universities in Korea. Given the reverse results, we have found that practical research motives were more important for revenues.

Secondly, while the determinant of total research funds is a critical resource for revenue, research funds received from the government are negatively related to revenues. It is also interesting to note that while research funds received from the government in the short term are not directly bringing any revenue to each university, government subsidies are bringing benefits to university as return in the long term. In addition, the volume of research funds is very important for the revenue. But, the characteristics of research funds are important. In this paper, research funds sponsored by enterprises affect the revenue, whereas research funds received by the government are insignificant. In order to make a profit, the nature of the fund is very important.

Third, incentive rules for inventors or developers of the technology have a positive relation for revenue in United States, whereas any incentive rules for inventors or developers are insignificant at Korean universities. The results are conspicuously different. It is also implied that the incentive systems do not operate well due to lack of experience or beneficiaries did not report a positive result due to a short implementation period. It can be assumed that this originates from the early stages of entrepreneurial universities.

Unlike our expectations, commercialization of technology transfer, profit of technology transfer, and patents do not show effects on revenue. Interestingly, not profit of technology transfer but the number of technology transfers per staffs working at 
TLO is significant. Despite the insignificant result here, other studies find that technology transfer and patents are critical determinants when it comes to entrepreneurial universities. Given the fact that Korea is a latecomer in this regard, the role of IUCF should be encouraged. As far as technology commercialization using patents is concerned, Korean universities are at an early stage assuming such activity.

Fourth, external conditions are also very important for revenue. From results, it is noted that firms without the firm size and firm specifics in proximity are good partners for revenue generation through exchange of technology and knowledge.

The contribution of this paper is that it is the first research on entrepreneurial universities supported by empirical evidence. In addition, this study covers all kinds of factors by categorizing variables such as university features, IUCF functions, and external conditions. Thus, this study is unique in treating such variables as determinants of revenue. Market economy in terms of utilizing the IUCF approach is useful in evaluating revenues of universities in developed countries such as the United States, a pioneer in operation of entrepreneurial universities.

This paper covers only a particular period between 2008 and 2010, whereas enactment of revised IUC law of 2008 has been in operation for a very short time. Therefore, there is a possibility that in this paper, policy effects might be not fully captured. Thus, it would be interesting to use updated data in future to verify if there would be any sign of improvement or maturation of revenue. Finally, several policy implications of the results must be discussed.

Firstly, while negative effects of distinguished faculty members in the regressions analysis is unexpected at first glance, it can be explained. It means simply that evaluation criteria for faculty member promotion have focused on the number of papers published. Distinguished scholars including general faculty members are inclined to write only academic papers rather than market-driven research. In that respect, thus, the findings endorse the elaboration of existing evaluation methods in order to pursue both academic study and market-driven research. In addition, when looking at the evaluation criterion before enactment Law on industrial education and industry-university cooperation (IUC law), the total number of papers was considered in keeping a position for promotion. That variety of accreditation rules are established is important to increase financial results

Secondly, the incentive system in Korea has not been successful until now as in the United States. When making new rules, Korean universities should follow the guidelines of the government. The government should eliminate tied regulation through deregulations, so universities are to be more flexible and adaptable to new regulations.

Thirdly, when it comes to characteristics of government research funds, the government should provide instructions for use of research funds to enhance its productivity in terms of practical research at the university level as well as academic studies at the national level.

Finally, in order to increase revenue, the government should deregulate strict rules related with entrepreneurial universities. As the role of IUCF is critical for the generation of financial revenue over time, policy makers should take into consideration the introduction of new modes to further vitalize the IUCF.

\section{References}

Agrawal, A. (2000), Importing scientific inventions: direct interaction, geography, and 
economic performance, Mimeo; Massachusetts Institute of Technology.

Audretsch, D. (2007), The entrepreneurial society, New York; Oxford University press.

Audretsch, D. and Feldman, M. (1996), R\&D spillovers and the geography of innovation and production, The American Economics Review, 86(3), 630-640.

Bercowitz, J. and Feldman, M. (2006), Entrepreneurial universities and technology Transfer, Journal of Technology Transfer, 31(1), 175-188.

Byun, C. (2004), The analysis on performance from industry-university collaboration, Research Paper in Korea Development Institutes.

Clark, B. (1998), Creating Entrepreneurial universities: Organizational pathways of Transformation, Oxford; International Association of University Press and Pergaman.

Clayton-Mathews A. (2001), The Medical Device Industry in Massachusetts, University of Massachusetts Boston.

Etzkowitz, H. (2004), The evolution of the entrepreneurial university, International Journal of Technology and Globalization, 1(1), 64-77.

Etzkowitz, H., A. Webster, C. Gebhardt and B.R.C. Terra (2000), The future of the university of evolution of Ivory Tower to Entrepreneurial paradigm, Research Policy, 29(2), 313-330.

Etzkowitz, H. (2003), Innovation in Innovation: The Triple Helix of UniversityIndustry- Government relations, Studies of Science, 42(3), 293-335.

Foltz, J., Barham, B. and Kim, K. (2000), Universities and agricultural biotechnology patent production, Agribusiness, 16(1), 82-95.

Friedman, J. and Silberman, J. (2003), University technology transfer: do incentive, management and location matter?, Journal of Technology Transfer, 28(1), 17-30.

Geiger, R.L. (2004), Knowledge and money: Research University and the paradox of the marketplace, California; Stanford University Press.

Geiger, R.L. and Creso, S.A. (2005), Beyond technology transfer: United Stated policies to harness university research for economic development, Minerva, 43, 121.

Hayrinen-Alestalo, M. and Peltola, U. (2006), The problem of market-oriented University, Higher Education, 52, 251-281.

Han, K. (2006), Opportunities and limitations of Engineering and Science specified universities: Unified variety, Journal of Korean Sociology, 40(2), 157-182.

Hanley, L. (2005), Academic capitalism in the new University, Radical Teacher, 73, 3-7.

Jaffe, A.R. and Henderson, R. (1993), Geographical localization of knowledge spillovers by patent citations, Quarterly Journal of Economics, 577-698.

Jensen. R. and Thursby, M. (2003), Disclosure and licensing of university inventions: the best we can do, International Journal of Industrial Organization 21, 12711300.

Joshua, B. and Patricia, P. (2005), University start-up formation and technology licensing with firms that go public; a resource-based view of academic entrepreneurship, Journal of Business Venturing, 20, 291 -311.

Kenney, M. and D. Patton (2009), Reconsidering the Bayh-Dole Act and the current university ownership model, Research Policy, 38, 1407-1422.

Kim, K. (2005), The study on commercialization from interactive between TLO and organizational environmental, Ph.D. Dissertation, Sungkyunkwan University.

Kim, C., and Lee, S. (2007), A study on relationships between performance of university-industry cooperation and competency factor of university, Journal of 
Korea Technology Innovation Society, 10, 629- 653.

KRF (2012), A White paper on University-Industry Cooperation 2010, Seoul, Korea (In Korean).

Kwon, S. and Han, K. (2009), The relationship between characteristics of university, structure of research fund and performance of industry-university cooperation, Journal of Korean Administration, 43(3), 307-325 (in Korean).

Naidoo, R. (2005), Universities in the marketplace: the distortion of teaching and research. In Barnett, R. (Ed), Reshaping the university: new relationships between research, scholarship and teaching. New York: Society for Research into Higher Education and Open University Press, 27-36.

O’Shea, R.P., T.J. Allen., C. Arnaud and F. Roche (2005), Entrepreneurial orientation, technology transfer and spinoff performance of U.S. universities, Research Policy, 34, 994-1009.

Powers, J.B. (2003), Commercializing Academic Research: Resource Effects on Performance of University Technology Transfer, The Journal of Higher Education, 74(1), 26-50.

Power, J.B. and McDougall, P.P. (2005), Policy orientation effects on performance with licensing to start-ups and Small companies, Research policy, 34(7), 1028-1042.

Rhoades, G. and Slaughter, S. (2004), Academic capitalism in the new economy: challenges and choices, American Academic, 1(1), 37-59.

Rothaermal, F.T., S.D. Agung, and L. Jiang. (2007), University entrepreneurship: A Taxonomy of the literature, Industrial and Corporate Change, 16(4), 691-791.

Sapsalis, E., Van Looy, B., Van pottelsberghe De La Potterie, B., Callaert, J. and Debavckere, K. (2006), Antecedents of patenting activity of European universities, Working Papers CEB 05-005.RS, university Lebre de Bruxelles, Solvay Business School, Centre Emile Bernheim.

Shane, S. (2004), Encouraging University Entrepreneurship?: The effect of the BayhDole Act on university patenting in the United States, Journal of Business Venturing, 19(1), 127-151.

Siegel, S., David, A. and Albert, L. (2003a), Assessing the impact of organizational practices on the relative productivity of university technology transfer offices: An exploratory study, Research Policy, 32(3), 27-48.

Siegel, S., David., A., Lean, E. and Albert, L. (2003b), Commercial knowledge transfer from universities to firms; Improving the effectiveness of university-industry collaboration, The Journal of High Technology Management Research, 14, 111-133.

Slaughter, S. and L.L. Leslie (1997), Academic capitalism: politics, policies and the entrepreneurial Universities, London; Johns Hopkins University.

Slaughter, S., and G. Rhoades (2004), Academic Capitalism in the New Economy. Baltimore, Md.: The Johns Hopkins University Press.

Sporn, B. (2001), Building Adaptive Universities: Emerging organizational forms based on experiences of European and US universities, Quarterly Education and Management, 7(2), 121-134.

Taylor, T. and Audretsch, D. (2011), The Bayh-Dole Act and Scientist Entrepreneurship, Research policy, 40(8), 1058-1067.

Thursby, J. G. and Thursby, M. (2002), Who is selling the ivory tower? Sources of growth in university licensing, Management Science, 48(1), 90-104.

Vallas, S. and Kleinman, D. (2008), Contradiction, convergence and the knowledge economy: the confluence of academic and commercial biotechnology, Socio- 
Economic Review, 6(2), 283-311.

Washburn, J. (2005), University, INC: The corporate corruption of American higher education, New York; Basic Books.

Wayne, K.T. (2010), Determinants of commercial innovation for University Technology Transfer, Journal of Behavioral Studies in Business, 21, 234-243.

Wong, P.K. (2007), Towards an Entrepreneurial university model to support knowledge-Based Economic Development: The case of the National University of Singapore, World Development, 35(6), 941-958.

Zemsky, R., S. Shaman and M. Iannozzi (1997), In search of strategic perspective: a tool for mapping the market in postsecondary education, Change, 29(6) 23-38. 


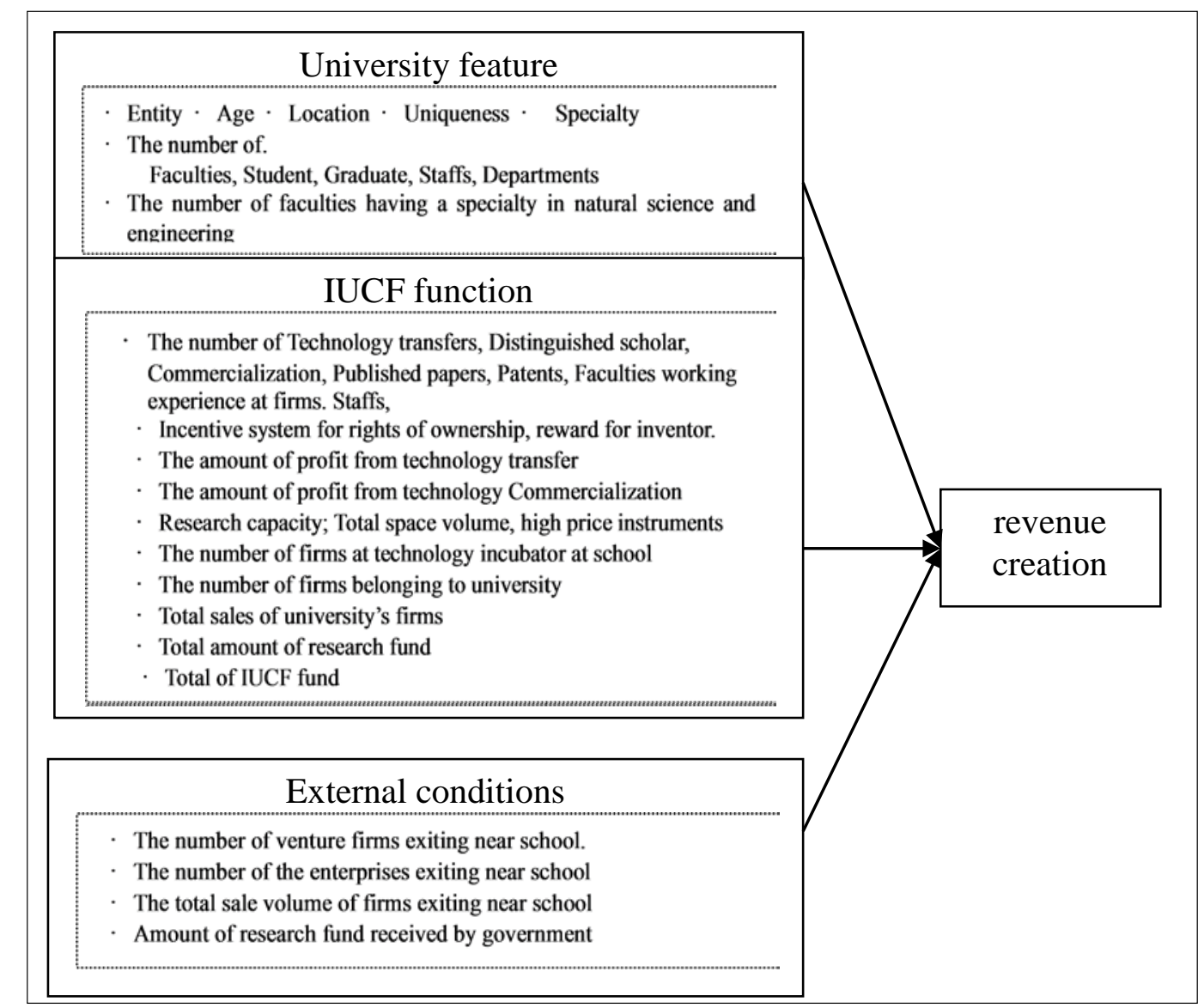

Figure 1: An analytical framework of research 
Appendix A: Policy instruments representing entrepreneurial university

\begin{tabular}{|c|c|c|}
\hline Constitutes & Factors & Theoretical Research \\
\hline $\begin{array}{l}\text { Subsidies for } \\
\text { universities }\end{array}$ & $\begin{array}{l}\text {-Cut back operating cost of university } \\
\text { •Designated research funds rather general } \\
\text { Research funds } \\
\text {-Selection and concentration subsidy } \\
\text { accredited by Government }\end{array}$ & $\begin{array}{l}\text { (Hanley, 2005; Naidoo, 2005; } \\
\text { Slaughter and Leslies, 1997; } \\
\text { Slaughter and Rhoades, 2004) }\end{array}$ \\
\hline $\begin{array}{l}\text { Research } \\
\text { policies }\end{array}$ & $\begin{array}{l}\text { - Facilitating applied research } \\
\text {-Subsiding research areas which are directly } \\
\text { related with nation innovation and } \\
\text { development } \\
\text { • Fostering research university }\end{array}$ & $\begin{array}{l}\text { (Rhoades and Slaughter, 2006; } \\
\text { Shane, 2004; Welsh et al. 2008; } \\
\text { Slaughter and Leslies, 1997; } \\
\text { Slaughter and Rhoades, 2004). }\end{array}$ \\
\hline $\begin{array}{l}\text { Intellectual } \\
\text { property }\end{array}$ & $\begin{array}{l}\text {-Handover of patent rights created by using } \\
\text { government research fund to university }\end{array}$ & $\begin{array}{l}\text { (Rhoades and Slaughter, 2006; } \\
\text { Shane, 2004) }\end{array}$ \\
\hline $\begin{array}{l}\text { Industry- } \\
\text { university } \\
\text { collaboration }\end{array}$ & $\begin{array}{l}\text {-Deregulation rules } \\
\text {-Support university revenue using } \\
\text { • Performance of university research } \\
\text { • Facilitating the establishment of professional } \\
\text { organization like technology transfer office } \\
\text { •Establishing start-ups using research } \\
\text { Performance at university } \\
\text {-Boosting the co-research activities related } \\
\text { with industrial demands }\end{array}$ & $\begin{array}{l}\text { (Geiger, 2004; Geiger and Creso, } \\
\text { 2005; Washburn, 2005; Hayrinen- } \\
\text { Alestolo and Pelotas, 2006; Slaughter } \\
\text { and Leslie, 1997; Slaughter and } \\
\text { Leslies, 1997; Slaughter and } \\
\text { Rhoades, 2004) }\end{array}$ \\
\hline
\end{tabular}


Appendix B: Previous research on performance of industry-university collaboration

\begin{tabular}{|c|c|c|}
\hline Researcher & Methodology & Findings \\
\hline $\begin{array}{l}\text { O’Shea et al. } \\
\text { (2005) } \\
\text { Byun (2004) }\end{array}$ & $\begin{array}{l}\text { Survey for } 107 \\
\text { universities in Korea }\end{array}$ & $\begin{array}{l}\text {-It shows that university scale, age of professional } \\
\text { institutions, and incentive systems for technology } \\
\text { developers have positive effects on revenue through } \\
\text { industry-university collaboration. }\end{array}$ \\
\hline Foltz et al. (2000) & $\begin{array}{l}\text { Survey for bio- } \\
\text { agricultural firms in } \\
\text { United States }\end{array}$ & $\begin{array}{l}\text { •Research funds received from federal government and } \\
\text { university have positive effects on revenue, while } \\
\text { research funds received from industries have no } \\
\text { relation with performance. }\end{array}$ \\
\hline $\begin{array}{l}\text { Friedman and } \\
\text { Silberman } \\
\text { (2003), } \\
\text { Jaffe et al. (1993) }\end{array}$ & Regression for 12 firms & $\begin{array}{l}\text {-The degree of proximity of high-tech firms near school } \\
\text { has positive effects on technology transfer. } \\
\text { •Geographical location of universities has positive } \\
\text { relation with knowledge spill over. }\end{array}$ \\
\hline Kim (2005) & $\begin{array}{l}\text { Survey for } 54 \\
\text { universities and } 79 \\
\text { firms in Korea }\end{array}$ & $\begin{array}{l}\text {-Level of education of experts working at technology } \\
\text { transfer office has a positive effect on revenue through } \\
\text { industry-university collaboration } \\
\text {-The number of patents has an effect on revenue through } \\
\text { industry-university collaboration }\end{array}$ \\
\hline $\begin{array}{l}\text { Sapsalis et al. } \\
\text { (2006) }\end{array}$ & $\begin{array}{l}\text { Regression for } 89 \\
\text { universities in United } \\
\text { States. }\end{array}$ & $\begin{array}{l}\text {-Scientific competency, the number of papers, and } \\
\text { patents have a positive effect on revenue through } \\
\text { industry-university collaboration. }\end{array}$ \\
\hline Seo et al. (2005) & Descriptive & $\begin{array}{l}\text { •University’s own firms based on university’s own } \\
\text { technology and holding companies are related with } \\
\text { revenue through industry-university collaboration. }\end{array}$ \\
\hline $\begin{array}{l}\text { Kwon and Han } \\
\text { (2009) }\end{array}$ & $\begin{array}{l}\text { Regression for } 169 \\
\text { universities in Korea, } \\
\text { Explorative }\end{array}$ & $\begin{array}{l}\text {-Public universities have higher performances than those } \\
\text { of private universities in terms of the number of } \\
\text { technology transfers and the amount of technology } \\
\text { licensing fees. } \\
\text {-The characteristics of university such as age, size, } \\
\text { number of departments, faculty members, students, } \\
\text { and experts, the number of SCIE papers are not } \\
\text { statistically related to performances. } \\
\text { • Regional universities have higher performance than } \\
\text { universities in urban areas in terms of technology } \\
\text { transfer. }\end{array}$ \\
\hline $\begin{array}{l}\text { Kim and Lee } \\
\text { (2007) }\end{array}$ & $\begin{array}{l}\text { Regression } 61 \\
\text { universities in Korea }\end{array}$ & $\begin{array}{l}\text {-Research competency such as the number of SCIE } \\
\text { papers and the number of patent registrations were } \\
\text { significant, but managerial competency such as the } \\
\text { scale of technology transfer organizations and the } \\
\text { number of specialists was not statistically significant. }\end{array}$ \\
\hline Power (2003) & $\begin{array}{l}\text { Interview and } \\
\text { Regression for } 66\end{array}$ & $\begin{array}{l}\text { - Research funds including both public and private have a } \\
\text { positive correlation with patent products. But this is }\end{array}$ \\
\hline
\end{tabular}




\begin{tabular}{|l|l|l|}
\hline & $\begin{array}{l}\text { enterprises and 312 } \\
\text { university researchers. }\end{array}$ & $\begin{array}{c}\text { not related to revenue through the licensing. } \\
\bullet \text { The more distinguished faculty member a university } \\
\text { has, the more patents and licensing a university has. }\end{array}$ \\
\hline $\begin{array}{l}\text { Sigel et al. } \\
\text { (2003a) }\end{array}$ & $\begin{array}{l}\text { Interview and } \\
\text { Regression for 98 } \\
\text { people who are directly } \\
\text { related to TTO in US }\end{array}$ & $\begin{array}{l}\text {-Reward systems for interested persons have effects on } \\
\text { performance. }\end{array}$ \\
\hline $\begin{array}{l}\text { Jenson and } \\
\text { Thursby (2003) }\end{array}$ & $\begin{array}{l}\text { Interview and } \\
\text { Regression (2003) }\end{array}$ & $\begin{array}{l}\text { •Reward system through technology transfer is directly } \\
\text { related with performance. }\end{array}$ \\
\hline $\begin{array}{l}\text { Thursby and } \\
\text { Thursby (2002) }\end{array}$ & $\begin{array}{l}\text { Survey for 64 } \\
\text { universities in US }\end{array}$ & $\begin{array}{l}\text {-The number of faculty members, experts, and interested } \\
\text { persons working at TTO's and relationship with } \\
\text { external firms are related with performance. } \\
\text { - }\end{array}$ \\
\hline $\begin{array}{l}\text { Joshua and } \\
\text { Patricia (2003) }\end{array}$ & $\begin{array}{l}\text { Regression for 108 } \\
\text { universities in US }\end{array}$ & $\begin{array}{l}\text { Age of TTO, the number of outstanding engineering } \\
\text { faculty members, and research funds received by } \\
\text { external organizations have a positive relation with } \\
\text { performance, respectively. }\end{array}$ \\
\hline
\end{tabular}


Appendix C: Summary and Definition of variables, period 2010-2011, N=139 universities

\begin{tabular}{|c|c|}
\hline Variables & Description \\
\hline School type & If a school is included private, then 1. \\
\hline School age & $\begin{array}{l}\text { If a school is less than } 10 \text { year, then } 1 \\
\text { If a school is } 11 \leq \text { year }<20 \text {, then } 2 \text {. } \\
\text { If a school is } 21 \leq \text { year }<30 \text {, then } 3 \text {. } \\
\text { If a school is } 31 \leq \text { year }<40 \text {, then } 4 \text {. }\end{array}$ \\
\hline Location & If school is located in Seoul and Kyunggi area, then 1. \\
\hline Special & If the number of graduate students is more than $10 \%$ of total enrollment numbers, than 1 . \\
\hline Unique & $\begin{array}{l}\text { If a school has more than } 40 \% \text { of faculty members having specialty in natural science or } \\
\text { engineering, then } 1 .\end{array}$ \\
\hline Faculty & Total number of faculty members in a school \\
\hline Facueng & Number of faculty members in engineering departments \\
\hline Grastud & Number of graduate students in school \\
\hline Undstud & Number of undergraduate students \\
\hline Distisch & Number distinguished scholars enrolled Marquis Who’s Who \\
\hline Resfund & Amount of total research funds \\
\hline Uninfun & Amount of industry-university cooperation funds received by university and industry \\
\hline Volsubs & Amount of total public funds received by government \\
\hline Placres & Total space volume for research activities \\
\hline Totsalr & Total sales of firms located in nearby school \\
\hline Stafuni & Number of staffs at school \\
\hline Pappubl & Number of published papers including those published in foreign journals \\
\hline Patappl & Number of patent applications including those registered in foreign countries \\
\hline Patappr & Number of patent approvals \\
\hline Priinst & Total price of laboratory instruments. \\
\hline Fexpfac & Number of faculty members with working experience in firms \\
\hline Firmreg & Number of firms located near schools \\
\hline Totprod & Total product volume of firm existing near schools \\
\hline Nstafuid & Number of staff in industry-university cooperation foundation (IUCF) \\
\hline Agetectr & Number of commercialization through technology transfer \\
\hline Unibudg & Total volume of university budget \\
\hline Nstafttd & Number of technology transfer per staff who are working at technology transfer divisions \\
\hline Nulerown & If a school has a rule for rights of ownership, then 1. \\
\hline Nulerinv & If a school has a rule for rewards for inventor or developer, then 1. \\
\hline Rulerett & If a school has rule for reward from technology transfer, then 1 \\
\hline Techtdiv & Technology transfer division \\
\hline Studint & Number of students participating in internships. \\
\hline Techtra & Number of technology transfers \\
\hline Venfirm & Number of venture firms \\
\hline Totsales & Total sales of the firms owned by school \\
\hline Nschfirm & Number of firms belonging to university \\
\hline Profttr & Amount of profits through technology transfer \\
\hline Ntecincb & Number of firms within technology incubator at school \\
\hline Revenue & Amount of revenue through university-industry collaboration \\
\hline
\end{tabular}

